\begin{tabular}{|l|l|l||}
\hline \multicolumn{2}{|c|}{ PublisherInfo } \\
\hline \hline PublisherName & $:$ & BioMed Central \\
\hline \hline PublisherLocation & $:$ & London \\
\hline \hline PublisherImprintName & $:$ & BioMed Central \\
\hline \hline
\end{tabular}

\title{
Valve incompetence: a hazard of internal jugular vein cannulation
}

\begin{tabular}{|l|l|l||}
\hline \multicolumn{2}{|c||}{ ArticleInfo } \\
\hline \hline ArticleID & $:$ & 4223 \\
\hline \hline ArticleDOI & $:$ & $10.1186 /$ ccf-2000-6419 \\
\hline \hline ArticleCitationID & $:$ & 6419 \\
\hline \hline ArticleSequenceNumber & $:$ & 82 \\
\hline \hline ArticleCategory & $:$ & Paper Report \\
\hline \hline ArticleFirstPage & $:$ & 1 \\
\hline \hline ArticleLastPage & $:$ & 3 \\
\hline \hline & & RegistrationDate : 2000-9-14 \\
\hline ArticleHistory & $:$ & OnlineDate \\
\hline \hline ArticleCopyright & $:$ & Current Science Ltd2000-9-14 \\
\hline \hline ArticleGrants & $:$ & \\
\hline \hline ArticleContext & $:$ & 1305422 \\
\hline \hline
\end{tabular}


Aff1 Princess Margaret Hospital, Swindon

\section{Keywords}

Central venous catheter, colour Doppler, complication, intracerebral venous blood pressure

\section{Comments}

A competent internal jugular vein valve prevents backward flow of blood when intrathoracic pressure suddenly increases. A competent valve is of theoretical benefit in cardiopulmonary resuscitation (when backward flow would impair the artificial circulation), in patients with critically raised intracranial pressure during positive pressure ventilation and when coughing. This study shows two things. First, cannulation of the internal jugular vein is likely to cause valvular incompetence which is often still present after 3 months. Secondly, 24\% of patients presenting for cardiac surgery already have valvular incompetence even before any intervention on their internal jugular vein. The most important question (that the paper does not address) is whether any of this actually matters. I remain to be convinced; particularly in view of the relatively common occurrence of an incompetent valve in patients who do not have internal jugular lines.

\section{Introduction}

Several problems may arise if the internal jugular vein valve is rendered incompetent. Only $90 \%$ of humans have such a valve, but there is evidence that puncturing it causes valvular incompetence. The question this study addressed was whether a high approach to internal jugular vein puncture reduced the incidence of internal jugular vein valve damage.

\section{Methods}

- A total of 126 patients scheduled for elective cardiac surgery who had not previously had a central line were recruited 
- Of these, $24 \%$ were later excluded for preexisting internal jugular vein valve incompetence

- Patients were randomised to receive either a high approach (1 $\mathrm{cm}$ above cricoid cartilage) or a low approach ( $1 \mathrm{~cm}$ below) to internal jugular vein puncture

- Colour Doppler ultrasound was then used to assess the blood flow through the internal jugular vein preoperatively, 3-4 days postoperatively before the line was removed, just after removal, and 8 to 27 months later

\section{Results}

Incompetence of the jugular vein valve was frequently found postoperatively, $76 \%$ with the low approach, $41 \%$ with the high approach (statistically significant). This persisted when the catheter was removed (47\% low and $28 \%$ high). In total, 24 patients still had incompetence at late testing.

\section{References}

1. Wu X, Studer W, Erb T, Skarvan K, Seeberger MD: Competence of the internal jugular vein valve is damaged by cannulation and catheterization of the internal jugular vein. Anesthesiology. 2000, 93 :

319-324. 